\title{
PERTUMBUHAN DAN CARA KERJA DPR-RI PASCA REFORMASI
}

\author{
Saefullah Yamin, \\ Nurwahyuni \\ Universitas Wiralodra \\ Email : ifoelyamin@gmail.com, \\ nurwahyuni689@yahoo.com
}

\begin{abstract}
Post reformation of the role and function of the House of Representatives of Republik Indonesaian (DPR RI) is returned to its corridor as a legislative institution that runs the legislative function (making laws/constitution), besides running budgeting fungction together with the president, and the oversight function of the implementation of the law and the budget in the administration of government carried out by the executive. Related to the lack of productivity of The House of Representatives (DPR) to carry out the legislative function, The performance evaluation of this legislation is not only seen in terms of the quantity of products made but its quality is also an important factor in assessing legislation products. The identification problems in this research are: What is the Position of the House of Representatives in the 1945 Constitution of the State of the Republic of Indonesia, and What is the Process of the Growth of the Post-Reformation House of Representatives. In this research the library research method will be used or library research. Regarding this kind of research it is usually also called "Legal Research" or "Legal Research Instruction". The position of The House of Representatives (DPR) after the amendment of the 1945 Constitution four times turned out to further strengthen its existence as the sole legislator. Although in the 1945 Constitution the amendment results also gave the President authority, but the authority he owned was not as big as The House of Representatives (DPR). And the process of the growth of the House of Representatives (DPR) Post-Reformation has strengthened the authority of the legislative instituion, in this case the House of Representatives of Republik Indonesian (DPR-RI) to maximize its role and function as a check and balances institution, after being strengthened, the House of Representatives (DPR) becomes tyrannical over the executive even over the state, because of its power and authority so great.
\end{abstract}

Keywords: Function of the House of Representatives of Republik Indonesaian (DPR RI), Development of the House of Representatives of Republik Indonesaian (DPR RI), The new order

\section{PENDAHULUAN}

Pasca Reformasi 1998 telah mendorong lembaga DPR RI menjadi lebih demokratis dan akuntabel. Hal tersebut setidaknya memberikan performance baru bagi DPR yang sebelumnya dinilai kurang berperan dalam menjalankan fungsinya pada masa Orde Baru, maka pasca reformasi peran dan fungsi DPR RI dikembalikan ke koridornya sebagai lembaga legislatif yang menjalankan fungsi legislasi (membuat Undang-undang), selain juga 
menjalankan fungsi budgeting (anggaran) bersama-sama dengan presiden, serta fungsi pengawasan atas pelaksanaan UU dan anggaran dalam penyelenggaraan pemerintahan yang dilakukan oleh eksekutif ${ }^{1}$.

Akhir-akhir ini pers, mahasiswa dan masyarakat sering menyoroti dan menilai kedudukan, fungsi dan tugas DPR RI hanya sebagai "Tukang Stempel" atau "Lembaga Stempel" atas keinginan dan kehendak politik pemerintah atau pihak eksekutif.

Dalam menjalankan fungsinya, DPR periode 2014-2019 dinilai sangat rendah kinerjanya terutama dalam menjalankan fungsi legislasi. Fungsi legislasi dilaksanakan sebagai perwujudan DPR selaku pemegang kekuasaan membentuk undang-undang. Fungsi ini paling dominan dan berpengaruh, karena melalui fungsi ini maka DPR dapat mempengaruhi semua aspek yang ada di Negara Indonesia.

Fungsi dan kedudukan DPR RI telah diatur dalam UUD 1945 dalam kehidupan bernegara secara demokratis. Pejuang kemerdekaan secara konkrit telah menjiwai dan menegaskan bahwa Indonesia merdeka haruslah memiliki aparatur negara yang demokratis seperti yang tertuang dengan jelas dalam pancasila dan dalam cara kerja Badan Penyelidik Usaha-usaha Persiapan Kemerdekaan (BPUPK) dan panitia persiapan Kemerdekaan Indonesia (PPKI) pada Tahun 1945.

Dalam kerjanya, BPUPK dan PPKI telah merumuskan dan memutuskan berbagai langkah perwujudan kemerdekaan RI dan Penerimaan Naskah UUD 1945 yang dilakukan secara demokrasi melalui pemungutan suara ${ }^{2}$.

Sikap hati-hati dalam langkah demokratis para perintis kemerdekaan RI adalah cermin dan akar yang kuat dari tradisi dan budaya bangsa Indonesia, serta hasil dari pembelajaran bangsa-bangsa di dunia.

Alasan dan latar belakang inilah, bahwa perintis kemerdekaan RI secara sadar dan bertanggung jawab merumuskan dengan jelas dan konkret bahwa sistem pemerintahan atau kehidupan bernegara RI haruslah demokratis.

Bukti cita demokrasi di Indonesia tertuang dalam Pancasila dan dalam Pasal-pasal UUD 1945, yang dapat dibagi dalam tiga kelompok rumusan yang satu sama lain saling berkaitan, Rumusan pembukaan UUD 1945, Rumusan Kedaulatan Adalah Di Tangan

\footnotetext{
${ }^{1}$ Ratnia Solihah, Siti Witianti, Pelaksanaan Fungsi Legislasi Dewan Perwakilan Rakyat Pasca Pemilu 2014: Permasalahan Dan Upaya Mengatasinya, Jurnal Ilmu Pemerintahan, (CosmoGov, Vol.2 No.2, Oktober 2016), hlm. 292.

2 B.N. Marbun, DPR RI- Pertumbuhan dan Cara Kerjanya, PT. Gramedia Pustaka Utama, Jakarta, 1992, hlm. 3.
} 
Rakyat Dan Dilakukan Sepenuhnya Oleh Majelis Permusyawaratan Rakyat, Rumusan Tentang Dewan Perwakilan Rakyat.

Terkait dengan kurang produktifnya DPR menjalankan fungsi legislasi, Penilaian kinerja legislasi ini tidak hanya dilihat dari sisi kuantitas produk yang dibuat namun kualitasnya juga menjadi faktor penting dalam menilai produk legislasi. Akan tetapi, alasan untuk mengejar kualitas dengan mengabaikan kuantitas juga bisa menjadi persoalan pada saat pencapaiannya sangat minim dibandingkan dengan perencanaan yang telah disusun.

Berdasarkan uraian latar belakag tersebut, penulis tertarik untuk melakukan pengkajian dalam bentuk karya ilmiah dengan judul "PERTUMBUHAN DAN CARA KERJA DPR-RI PASCA REFORMASI" adapun identifikasi masalahnya adalah sebagai berikut, Bagaimanakah Posisi Dewan Perwakilan Rakyat Dalam Undang-undang Dasar Negara Republik Indonesia Tahun 1945, dan Bagaimanakah Proses Pertumbuhan Dewan Perwakilan Rakyat Pasca Reformasi.

Berkaitan dengan adanya polemik pertumbuhan kinerja DPRI Pasca Reformasi, maka peneliti mengajukan rumusan masalah penelitian sebagai berikut:

1. Bagaimanakah Posisi Dewan Perwakilan Rakyat Dalam Undang-undang Dasar Negara Republik Indonesia Tahun 1945?

2. Bagaimanakah Proses Pertumbuhan Dewan Perwakilan Rakyat Pasca Reformasi?

\section{METODE}

Sebagai ilmu normatif, ilmu hukum memiliki cara kerja yang khas sui generis ${ }^{3}$. Penelitian ini merupakan penelitian hukum (penelitian yuridis) yang memiliki suatu metode yang berbeda dengan penelitian lainnya. Metode penelitian hukum merupakan suatu cara yang sistematis dalam melakukan sebuah penelitian ${ }^{4}$.

Dalam penelitian karya ilmiah dapat menggunakan salah satu dari tiga bagian grand methode yaitu library research, ialah karya ilmiah yang didasarkan pada literatur atau pustaka; field research, yaitu penelitian yang didasarkan pada penelitian lapangan; dan bibliographic research, yaitu penelitian yang memfokuskan pada gagasan yang terkandung dalam teori.

\footnotetext{
${ }^{3}$ Sui generis dalam peristilahan hukum adalah ilmu hukum merupakan ilmu jenis sendiri dalam hal cara kerja dan sistem ilmiah. Peter Mahmud Marzuki, Penelitian Hukum, Kencana Prenada Media group, Jakarta, 2005.

${ }^{4}$ Abdulkadir Muhammad, Hukum Dan Penelitian Hukum, PT. Citra Aditya Bakti, Bandung, 2004, hlm. 57.
} 
Berdasarkan pada subyek studi dan jenis masalah yang ada, maka dari tiga jenis grand method yang telah disebutkan, dalam penelitian ini akan digunakan metode penelitian library research atau penelitian kepustakaan. Mengenai penelitian semacam ini lazimnya juga disebut "Legal Research" atau "Legal Research Instruction", Penelitian hukum semacam ini tidak mengenal penelitian lapangan (field research) karena yang diteliti adalah bahan-bahan hukum sehingga dapat dikatakan sebagai library based, focusing on reading and analysis of the primary and secondary materials ${ }^{6}$.

\section{HASIL DAN PEMBAHASAN}

\subsection{Posisi DPR RI Dalam UUD 1945}

Permasalahan yang paling utama dan pokok dalam pergeseran nilai Ilmu Hukum Tata Negara dan Politik sepanjang sejarah terdapat dalam sebuah mekanisme hubungan antara Negara dan rakyat dalam suatu Negara dan bangsa, Kepentingan Negara dan bangsa bisaanya diwakili oleh pemerintah sedangkan kepentingan rakyat yang sifatnya diinstitusionalkan atau terlembagakan melalui sebuah parlemen baik parlemen yang bersifat Unikameral (Monokameral) ada juga yang bersfiat bicameral dan bahkan ada pula parlemen yang bersifat trikameral seperti Negara china namun tak menutupi pula seperti negara Indonesia yang memiliki karakter tersendiri dalam pemerintahan mengakui adanya otonomi daerah yang memang sering sekali pergeseran ini sangatlah terjadi.

Pasca Bangsa Indonesia memproklamirkan kemerdekaan 17 Agustus 1945, perintis kemerdekaan telah merancang UUD 1945 sebagai landasan pedoman kerja negara Republik Indonesia. Tujuan tersebut di cantumkan dalam alenia ke empat UUD 1945 yaitu: ${ }^{7}$

Negara bertujuan untuk memberikan perlindungan kepada segenap bangsa Indonesia dan seluruh tumpah darah Indonesia, memajukan kecerdasan umum dan mencerdaskan kehidupan bangsa serta ikut memelihara ketertiban dunia yang didasarkan kemerdekaan, perdamaian dan keadilan sosial.

Kedudukan lembaga tertinggi dan lembaga tinggi negara, serta hubungan antar lembaga-lembaga sebelum amandemen, UUD 1945 mengatur MPR adalah lembaga tertinggi negara, dan MPR mendistribusikan kekuasaannya (distribution of power) kepada 5

\footnotetext{
5 Soerjono Soekanto dan Sri Mamudji, Penelitian Hukum Normatif Tinjauan Singkat, Rajawali Pers, Jakarata 2006, hlm. 23.

6 Jhonny Ibrahim, Teori dan Metodologi Penelitian Hukum Normatif, Bayumedia Publishing, Malang, 2006, hlm. 46.

7 Op Cit, DPR RI- Pertumbuhan dan Cara Kerjanya, PT. Gramedia Pustaka Utama, Jakarta, 1992, hlm. 23.
} 
lembaga tinggi yang sejajar kedudukannya, yaitu Mahkamah Agung (MA), Presiden, Dewan Perwakilan Rakyat (DPR), Dewan Pertimbangan Agung (DPA) dan Badan Pemeriksa Keuangan (BPK). Sebagai lembaga tinggi negara, DPR sebelum amandemen UUD 1945 memiliki kewenangan yang cukup terbatas. Hal ini tertulis dalam UUD 1945 Pasal 20 ayat 1 (Memberikan persetujuan atas RUU), Pasal 21 ayat 1 (Mengajukan RUU), Pasal 22 ayat 2 (Memberikan persetujuan atas PERPU) dan Pasal 23 ayat 1 (Memberikan persetujuan atas Anggaran Pendapatan dan Belanja Negara). UUD 1945 pun tidak dengan jelas menyebutkan bahwa DPR memiliki fungsi legislasi, anggaran dan pengawasan.

Amandemen UUD 1945 meniadakan MPR sebagai lembaga tertinggi negara, sehingga MPR memiliki kedudukan yang sejajar dengan lembaga-lembaga negara lainnya. Kesejajaran antara lembaga-lembaga negara ini mengakibatkan terciptanya mekanisme pengawasan (check and balances) antar lembaga-lembaga negara.

Penerjemahan isi Undang-undang Dasar 1945 pasca Amandemen dalam pasalnya mempertegas eksistensi Dewan Perwakilan Rakyat (DPR) buktinyata di tegaskan dalam Pasal 1 ayat (2) UUD 1945 bahwa, kedaulatan ada di tangan rakyat dan dilakukan sepenuhnya oleh Majelis Permusyawaratan Rakyat. Lebih di tegaskan lagi dalam Pasal 5 ayat (1) UUD $1945^{8}$ bahwa Presiden mempunyai kekuasaan membentuk Undang-undang dengan Persetujuan Dewan Perwakilan Rakyat.

Pasal ini menunjukan bahwa Negara Indonesia bukanlah negara diktator oleh karenanya pemerintah atau dalam hal ini presiden mempunyai hak inisiatif untuk mengajukan Rancangan Undang-undang (RUU) yang penyelesaiannya harus mendapat pembahasan dan persetujuan DPR RI, oleh karenanya kedudukan DPR tidaklah diatas Presiden atau di bawah Presiden, akan tetapi kedudukannya di samping presiden bekerja sama menyusun undang-undang.

Tugas membentuk Undang-undang merupakan tugas DPR bukan MPR, meskipun presiden tidak bertanggung jawab kepada DPR, ia harus bekerja sama dengan DPR dalam pembentukan undang-undang dan menetapkan anggaran Pendapatan dan Belanja Negara (APBN) untuk setiap tahun anggaran.

\footnotetext{
${ }^{8}$ Lihat Pasal 5 ayat (1) UUD 1945.
} 
Dalam pembukaan UUD 1945, secara eksklusif dan inklusif eksistensi dan posisi DPR diatur secara rinci dalam Bab VII UUD 1945, yaitu dalam Pasal 19, 20, 21 dan 22. Dalam UUD 1945 telah di atur secara jelas fungsi dan kewajiban DPR antara lain:

Pasal 19 UUD 1945 menetapkan bahwa susunan Dewan Perwakilan Rakyat (DPR) ditetapkan dengan Undang-undang serta DPR bersidang sedikitnya satu kali dalam satu tahun 9 .

Setiap undang-undang menghendaki persetujuan DPR, jika suatu rancangan UU tidak mendapat persetujuan DPR, rancangan tersebut tidak dapat digunakan dalam persidangan DPR saat itu ${ }^{10}$.

Rancangan undang-undnag dapat dimajukan oleh anggota DPR, meskipun rancangan tersebut di setujui oleh anggota DPR tetapi tidak di sahkan oleh presiden rencangan tersebut tidak dapat dimajukan lagi dalam persidangan DPR saat itu ${ }^{11}$.

Jika kita tafsir lebih jauh ketentuan Pasal 20 dan 21 UUD 1945 memberikan keseimbangan kepada pihak presiden dan DPR, oleh karenanya rumusan ini memperkuat tafsiran bahwa keseimbangan kedudukan DPR dan Presiden bertujuan untuk mengurangi kemungkinan penyalahgunaan hak membuat undang-undang yang tidak mencerminkan kebutuhan aktual serta mendapat saling pengertian dan persetujuan dari pihak eksekutif dan legislatif.

Hak DPR dalam mengimbangi Presiden diatur dalam Pasal 5 UUD 1945 yaitu, presiden dapat memegang kekuasaan penuh membentuk udang-undang melalui persetujuan dari DPR, presiden juga dapat menetapkan Peraturan Pemeritah untuk menjalankan undangundang sebagaimana mestinya ${ }^{12}$.

Jaminan kerjasama yang saling menghargai kekuasaan, hak, serta wewenang antara Presiden dan DPR dipertegas dalam penjelasan UUD 1945 Bab VII Dewan Perwakilan Rakyat Pasal 19, 20, 21 dan 23 yang menjelaskan bahwa:

Dewan harus memberikan persetujuan kepada tiap-tiap rancangan Undang-undang dari pemerintah, dewan mempunyai hak inisiatif untuk menetapkan undang-undang, dewan mempunyai hak begrooting yang dijelaskan dalam Pasal 23 UUD 1945 dengan ini DPR

\footnotetext{
9 Lihat Pasal 19 ayat (1) dan (2) UUD 1945

${ }^{10}$ Lihat Pasal 20 ayat (1) dan (2) UUD 1945

${ }^{11}$ Lihat Pasal 21 ayat (1) dan (2) UUD 1945

${ }^{12}$ Lihat Pasal 5 ayat (1) dan (2) UUD 1945
} 
dapat mengontrol pemerintah, harus di ingat pula, bahwa semua anggota Dewan merangkap menjadi anggota Majelis Permusyawaratan Rakyat MPR.

Undang-undang Dasar 1945 memberikan bobot dan jalan keluar dalam situasi yang memaksa tanpa melanggar ketentuan saling menghormati kekuasaan antara presiden dan Dewan Perwakilan Rakyat seperti yang termaktub dalam ketentuan Pasal 22 UUD 1945 yang berbunyi: ${ }^{13}$

(1) Dalam hal ihwal kepentingan yang memaksa, Presiden berhak menetapkan Peraturan Pemerintah sebagai pengganti Undang-undang.

(2) Peraturan Pemerintah itu harus mendapat persetujuan Dewan Perwakilan Rakyat dalam pesrsidangan yang berikut.

(3) Jika tidak mendapat persetujuan, maka Peraturan Pemerintah itu harus dicabut.

Kekuasaan ke tangan DPR bertambah banyak dengan adanya kewenangan untuk mengisi beberapa jabatan strategis kenegaraan. Pertama, berdasarkan ketentuan Pasal 23F ayat 1 dalam hal memilih anggota Badan Pemeriksa Keuangan (BPK). Kedua, berdasarkan ketentuan Pasal 24C adalah menentukan tiga dari sembilan orang hakim Mahkamah Konstitusi. Ketiga, menjadi institusi yang paling menentukan dalam proses pengisian lembaga non-state lainnya (auxiliary bodies) seperti Komisi Nasional Hak Asasi Manusia, dan Komisi Pemilihan Umum. Kekuasaan ini akan bertambah dengan adanya keharusan untuk meminta pertimbangan DPR dalam pengisian jabatan Panglima TNI, Kepala Kepolisian Negara RI (Kapolri) ${ }^{14}$.

Adapun susunan tugas dan wewenang DPR RI berdasarkan UUD 1945 antara lain:

Undang-undang Dasar 1945 jelas menggambarkan bahwa DPR memegang peranan penting dan kekuasaan atas pembentukan Undang-undangdi Negara Republik Indonesia. Hal ini tercermin di dalam Pasal 20 UUD 1945 dimana dikatakan bahwa fungsi legislatif hampir berada sepenuhnya di tangan DPR. Berkaitan dengan fungsi legislasi yang dimiliki oleh DPR RI, dapat kita kelompokkan tugas dan wewenangnya sebagai berikut :

1. Membentuk Undang-undangyang dibahas dengan presiden untuk mendapat persetujuan bersama.

\footnotetext{
${ }^{13}$ Lihat Pasal 22 UUD 1945.

${ }^{14}$ Saldi Isra, Lembaga Legislatif Pasca Amandemen UUD 1945, dalam Soewoto Mulyosudarmo, Pembaharuan ketatanegaraan Melalui Perubahan Konstitusi, Asosiasi Pengajar HTN dan HAN Jawa Timur, Malang, 2004, hlm. 329.
} 
2. Membahas dan memberikan persetujuan peraturan pemerintah pengganti Undang-undang

3. Menerima dan membahas usulan Rancangan Undang-undangyang diajukan Dewan Perwakilan Daerah (DPD) yang berkaitan dengan bidang tertentu dan mengikutsertakannya dalam pembahasan

4. Memperhatikan pertimbangan DPD atas RUU APBN dan RUU yang berkaitan dengan pajak, pendidikan dan agama.

Dewan Perwakilan Rakyat sekarang memiliki fungsi legislatif yang sangat kuat, bahkan jika Rancangan Undang-undangyang telah disetujui bersama pun tidak di tanda tangani oleh presiden, maka RUU tersebut sah menjadi Undang-undangdan wajib diundangkan ${ }^{15}$.

Dalam Menjalankan peran dan fungsinya sebagai badan legislatif, DPR dilindungi oleh konstitusi bahkan di dalam ketentuan Pasal 7C UUD 1945 dikatakan bahwa : "Presiden tidak dapat membekukan dan atau membubarkan Dewan Perwakilan Rakyat“. Ini menggambarkan betapa kuatnya posisi konstitusional DPR.

Fungsi legislasi yang dimiliki DPR diwujudkan dengan cara :

1) Penyusunan Prolegnas

Program Legislasi Nasional adalah instrument perencanaan program pembentukan Undang-Undang yang disusun secara berencana, terpadu dan sistematis.

Mekanisme penyusunan Prolegnas

a. Program Legislasi Nasional memuat daftar RUU yang akan dibahas oleh DPR dan Pemerintah untuk 5 (lima) tahunan dan 1 (satu) tahunan.

b. Secara keseluruhan, pembentukan Undang-undang dimulai dari perencanaan, persiapan, teknik penyusunan, perumusan, pembahasan, pengesahan, pengundangan dan penyebar luasan.

2) Pengajuan Rancangan Undang-undang

Pengajuan Rancangan Undang-undangdapat diajukan oleh 3 pihak, yaitu Presiden, DPR dan DPD. Apabila kita membandingkan fungsi DPR dalam bidang legislasi, sebelum

\footnotetext{
15 Jimly Asshiddiqie, Sengketa Kewenangan Konstitusional Lembaga Negara, cet. ketiga, Konstitusi Press,
} Jakarta, 2006, hlm. 77. 
dan sesudah amandemen UUD 1945, akan terlihat perbedaan yang cukup signifikan. Pada saat UUD 1945 belum diamandemen (zaman orde baru), DPR hanya bersikap pasif, usul inisiatif selalu berasal dari pihak eksekutif, dan DPR tinggal menyetujui, karena itu isu yang berkembang seolah-olah DPR hanya stempel pemerintah. Lemahnya peran dan fungsi konstitusional DPR tidak semata-mata karena sebab-sebab kultural atau ada di dalam diri DPR sendiri, tetapi lebih terletak pada sistem yang ada. Struktur yang ada memang menjadikan DPR kurang dapat berperan secara maksimal.

Menurut Jimly Assidiqie, fungsi legislasi menyangkut empat kegiatan, yaitu :

(1) prakarsa pembuatan undang-undang (legislative intiation);

(2) pembahasan rancangan Undang-undang (law making process);

(3) persetujuan atas pengesahan rancangan undang-undang (law enactment approval); dan

(4) pemberian persetujuan pengikatan atau ratifikasi atas perjanjian atau persetujuan internasional dan dokumen-dokumen hukum yang mengikat lainnya (Binding decision making on international agreement and treaties or other legal binding documents $)^{16}$.

Berdasarkan hal di atas, maka pada hakekatnya fungsi utama dari legislatif adalah membuat undang-undang (legislasi). Hal ini juga sejalan dengan fungsi-fungsi yang lain seperti, fungsi pengawasan (controlling) juga merupakan bagian dari fungsi legislasi, karena dalam menjalankan fungsi pengawasan tentunya terlebih dahulu melahirkan peraturan perundangan-undangan yang dijadikan sebagai acuan dalam melakukan pengawasan terhadap pemerintah dalam menjalankan tugasnya. Begitu juga fungsi anggaran (budgeting) yang merupakan sebagian dari fungsi legislasi karena untuk menetapkan Anggaran Pendapatan dan Belanja Negara (APBN) juga ditetapkan dengan Peraturan Perundangundangan setiap tahun anggaran.

Ada beberapa hal yang menyebabkan kurang maksimalnya pelaksanaan fungsi legislasi yang dijalankan oleh DPR antara lain juga berupa kendala dalam konteks mekanisme kerja DPR, yang menyebabkan banyaknya tugas yang telah dijadwalkan belum terlaksana secara maksimal, dimana banyaknya anggota DPR yang belum mematuhi apa yang menjadi kewajibannya. Dalam rapat pembahasan dan pengesahan Undang-undang

\footnotetext{
${ }^{16}$ Jimly Assiddiqie, Pengantar Ilmu HukumTata Negara, PT Raja Grafindo Persada. Jakarta, 2009, hlm. 300.
} 
jumlah anggota DPR harus hadir adalah $50 \%$, namun pada kenyataannya apabila yang hadir kurang $50 \%$ rapat paripurna walau dihadiri ketua dan wakil ketua DPRD tetap tidak bisa dilaksanakan karena menyalahi aturan suara dalam mengambil keputusan di DPR. Hal ini tentu berdampak terhadap waktu dalam pembahasan dan pengesahan yang diundur.

Terkait dengan kondisi tersebut, dapatlah dilihat bahwa kurangnya kinerja DPR menghasilkan produk legislasi adalah karena aspek ketaatan anggota dewan dalam memenuhi jadwal legislasi. Hal tersebut berdampak pada tertundanya rapat pembahasan RUU karena tidak tercapainya kuorum dalam rapat.

Demikian juga tentang Prolegnas sebagai instrument pembentukan Undang-undang yang belum ditaati oleh seluruh anggota dewan. Hal lain yang menjadi penyebab kurangnya peran DPR dalam menjalankan fungsi legislasi adalah faktor sumber daya manusia yang meliputi kualitas anggota DPR dan pengalaman anggota DPR tersebut dalam menjalankan tugasnya sebagai anggota Dewan.

Terkait dengan kondisi tersebut, dapatlah dilihat bahwa kurangnya kinerja DPR menghasilkan produk legislasi adalah karena aspek ketaatan anggota dewan dalam memenuhi jadwal legislasi. Hal tersebut berdampak pada tertundanya rapat pembahasan RUU karena tidak tercapainya kuorum dalam rapat. Demikian juga tentang Prolegnas sebagai instrument pembentukan Undang-undang yang belum ditaati oleh seluruh anggota dewan. Melemahnya fungsi pengawasan karena ketidak seimbangan kedudukan DPR dengan pemerintah ${ }^{17}$.

\subsection{Proses Pertumbuhan Dewan Perwakilan Rakyat Pasca Reformasi}

Pasca reformasi pada tahun 1998, terjadi perubahan besar-besaran dalam sistem hukum di Indonesia. Mulai dari amandemen konstitusi dan perubahan peraturan perundangundangan, hingga pembenahan sistem kerja aparat dan transformasi budaya hukum.

Pada era pasca reformasi, semangat dalam proses amandemen adalah pembatasan kekuasaan eksekutif yang pada rejim Orde Baru dianggap terlalu executive heavy, otoriter, dan menyumbat aspirasi publik. Selain itu, pengerdilan partai politik melalui berbagai cara juga menyebabkan kegerahan publik untuk memperkuat lembaga representasi dan pengawasan yang terjelma dalam tubuh DPR, Hasilnya, saat ini, DPR memiliki kekuasaan yang sangat besar, khususnya dalam pengawasan dan pengangkatan pejabat publik. DPR

\footnotetext{
${ }^{17}$ Dahlan Thaib dan Ni'matul Huda, Pemilu dan Lembaga Keterwakilan dalam Ketatanegaraan Indonesia, Jurusan Hukum Tata Negara Fakultas Hukum Universitas Islam Indonesia, 1992, hlm. xiv-xv.
} 
memegang suara kunci untuk menentukan pengangkatan mulai dari hakim agung, hakim konstitusi, Gubernur BI, kepala kepolisian, pejabat komisi negara, hingga direksi BUMN.

Kondisi ini mulai dipandang negatif karena menciptakan politisasi dan perdagangan kepentingan jabatan-jabatan publik. Peran pengawasan juga dianggap telah dijalankan secara eksesif sehingga menganggu jalannya pemerintahan. Pemerintah dianggap "tersandera" oleh kekuatan parlemen dalam merumuskan dan menjalankan kebijakannya.

Reformasi Hukum dan Ruang Publik Mencegah arah gerak pendulum reformasi hukum bukan berarti menentang segala upaya untuk mengembalikan sistem seperti dahulu kala. Apabila reformasi yang dikembangkan saat ini terbukti gagal, sudah tentu harus dilakukan upaya-upaya perbaikan yang berkelanjutan, termasuk mengembalikan kepada sistem yang semula apabila dirasa lebih memberikan manfaat.

Pasca runtuhnya Orde Baru, konsepsi tentang bagaimana negara diselenggarakan menjadi topik kunci dalam era awal reformasi saat itu. Bagaimana tidak, pada era Orde Baru kekuasaan eksekutif begitu dominan atau biasa disebut executive heavy, sehingga meminimalisasi peran DPR sebagai lembaga check and balances. Namun demikian, diperlukan adanya suatu metode untuk menjamin bahwa evaluasi yang dilakukan dapat berjalan secara sistematis, partisipatif, dan forward looking.

reformasi telah menghasilkan perubahan beberapa pasal dalam Undang-Undang Dasar 1945, termasuk di dalamnya berkenaan dengan DPR RI kini memiliki kedudukan yang strategis dalam menjalankan fungsi legislasi, anggaran, dan pengawasan, Hal ini tentunya berdampak pada semakin meningkatnya harapan masyarakat terhadap kinerja dewan.

DPR adalah badan legislatif yang mencerminkan fungsi pentingnya sebagai lembaga negara, salah satunya yaitu legislate, atau membuat undang-undang. Nama lain yang sering dipakai adalah Assembly yang mengutamakan unsur berkumpul (untuk membicarakan masalah-masalah publik) di beberapa negara lain, sering juga dinamakan Parliament, suatu istilah yang menekankan wadah untuk "bicara" dan merundingkan suatu urusan publik. Sebutan lain, lebih menggunakan istilah representasi atau keterwakilan, yang anggotaanggotanya.

Era reformasi muncul inisiatif untuk memberikan penguatan kewenangan kepada lembaga legislatif dalam hal ini DPR RI untuk memaksimalisai peran dan fungsinya sebagai 
lembaga check and balances ${ }^{18}$. setelah mendapat penguatan seperti itu, lembaga ini malah menjadi tirani atas eksekutif bahkan atas negara sekalipun, hal itu dikarenakan kekuasaan dan kewenangan yang dimilikinya begitu besar.Maka oleh beberapa tokoh sering disebut sebagai fenomena pergeseran dari executive heavy ke bentuk legislative heavy.

Sistem kontrol pada DPR dapat diadakan bila para aktor utama pengamandemen betul-betul mempunyai semangat constitutional engineering yang murni. Namun, benturan kepentingan politik, mengakibatkan reformasi konstitusi telah direkayasa untuk menguntungkan dan melimpahkan sebesar-besarnya kekuasaan pada DPR ${ }^{19}$.

Dengan memberikan kekuasaan penuh kepada DPR tanpa pembatasan-pembatasan yang jernih, maka telah membuka peluang bagi terjadinya constitutional hazard yaitu pelanggaran terhadap konstitusi. Dalam rangka modernisasi sistem politik, diperlukan terobosan yang inovatif dan bijak dalam modernisasi politik, menyelesaikan persoalan ini. Biasanya para pengamat atau beberapa kalangan akademisi mengajukan DPD sebagai solusi untuk menganugerahkan kepadanya kewenangan yang sama dengan DPR. Akan tetapi menurut penulis, dampaknyamalah akan memunculkan persoalan saling dominasi dan "perang" kesewenang-wenangan antara keduanya.

Diperlukannya kewenangan proporsional bagi DPR yang jelas dalam batasanbatasannya sebagai suatu lembaga negara disepakati dan diatur bersama antara DPR dengan Pemerintah (eksekutif). Untuk realisasinya diperlukan wadah musyawarah antara kedua lembaga tersebut dengan ditengahi oleh lembaga konstitusi seperti Mahkamah Konstitusi.

Sistem politik Indonesia yang khas dengan multipartai dapat menjadi positif dan juga negatif.Terkait dengan peran dan kewenangan DPR yang berisi dari anggota-anggota dari beragam partai politik yang menunjukkan pluralitas, harusnya dapat mementalkan anggapan oligarki di DPR. Dengan beragam ideologi, program dan kebijakan dari partai masingmasing dan dengan basis massa pendukung utamanya masingmasing, seharusnya itu menjadi bantahan akan sikap saling mengingatkan di internal DPR sendiri. Oleh karena, konsistensi peran dari partai-partai atau kadernya yang berada di DPR sangat dibutuhkan sebagai penyeimbang dan menyortir suatu kebijakan atau keputusan politik yang dibuat oleh DPR.

\footnotetext{
${ }^{18}$ Jimly Asshiddiqie, Format Kelembagaan Negara dan Pergeseran Kekuasaan dalam UUD 1945, FH UII Press, Yogyakarta, 2005.

${ }^{19}$ Denny Indrayana, “Ancaman Tirani DPR.” http://perpustakaan.bappenas. go.id/, Artikel diakses pada 08 Juli 2019.
} 


\section{PENUTUP}

\subsection{Simpulan}

Kedudukan Dewan Perwakilan Rakyat setalah dilakukan amandemen UUD 1945 sebanyak empat kali ternyata lebih memperkuat eksistensi sebagai satu-satunya pembentuk Undang-undang. Walaupun di dalam UUD 1945 hasil amandemen memberikan juga kewenangan kepada Presiden, tapi kewenangan yang dimiliki tidak sebesar DPR.

Proses Pertumbuhan Dewan Perwakilan Rakyat Pasca Reformasi memberikan penguatan kewenangan kepada lembaga legislatif dalam hal ini DPR RI untuk memaksimalkan peran dan fungsinya sebagai lembaga check and balances, setelah mendapat penguatan, DPR menjadi tirani atas eksekutif bahkan atas negara, hal itu dikarenakan kekuasaan dan kewenangan yang dimilikinya begitu besar.

\subsection{Saran}

Penguatan tersebut akan lebih baik jika dibarengi dengan tindakan pertanggungjawaban kewenangan bagi masing-masing anggota Dewan Perwakilan Rakyat guna mencerminkan sikap yang lebih kredibel dan progresif.

Pertumbuhan Dewan Perwakilan Rakyat yang semakin kuat dan bertumbuh Pasca Reformasi ini diharapkan menjadikan aspirasi masyarakat dapat tersampaikan dan terlaksana dengan maksimal, untuk itu diharapkan bagi seluruh lapisan masyarakat untuk dapat saling mengawasi dan mengkoreksi kinerja Dewan Perwakilan Rakyat.

\section{DAFTAR PUSTAKA}

\section{A. Buku}

Asshiddiqie, Jimly.Format Kelembagaan Negara dan Pergeseran Kekuasaan dalam UUD 1945. Yogyakarta: FH UII Press, 2005.

Assiddiqie, Jimly. Pengantar Ilmu HukumTata Negara. Jakarta: (PT Raja Grafindo Persada. 2009

B.N. Marbun, DPR RI- Pertumbuhan dan Cara Kerjanya, PT. Gramedia Pustaka Utama, Jakarta 1992 
Dahlan Thaib dan Ni'matul Huda, Pemilu dan Lembaga Keterwakilan dalam Ketatanegaraan Indonesia, Jurusan Hukum Tata Negara Fakultas Hukum Universitas Islam Indonesia, 1992

Denny Indrayana, “Ancaman Tirani DPR.” Artikel diakses pada 08 Juli 2014 dari http://perpustakaan.bappenas. go.id/

Jhonny Ibrahim, Teori dan Metodologi Penelitian Hukum Normatif, Bayumedia Publishing, Malang 2006

Jimly Asshiddiqie, Sengketa Kewenangan Konstitusional Lembaga Negara, ctk.ketiga, Konstitusi Press, Jakarta, 2006

Ratnia Solihah, Siti Witianti, Pelaksanaan Fungsi Legislasi Dewan Perwakilan Rakyat Pasca Pemilu 2014: Permasalahan Dan Upaya Mengatasinya, Jurnal Ilmu Pemerintahan, (CosmoGov, Vol. 2 No. 2, Oktober 2016)

Saldi Isra, Lembaga Legislatif Pasca Amandemen UUD 1945, dalam Soewoto Mulyosudarmo, Pembaharuan ketatanegaraan Melalui Perubahan Konstitusi, Asosiasi Pengajar HTN dan HAN Jawa Timur, Malang, 2004

Soerjono Soekanto dan Sri Mamudji, Penelitian Hukum Normatif Tinjauan Singkat, Rajawali Pers, Jakarata 2006

\section{B. Undang-undang}

Undang-Undang Dasar Negara Republik Indonesia Tahun 1945 